\title{
The Socio-economic Potential of the Emerging Film Industry in Saudi Arabia
}

\author{
By Lamia Saud Shesha ${ }^{1}$, Nadia Yusuf ${ }^{2}$
}

\begin{abstract}
The Kingdom of Saudi Arabia transformed from a developing Middle Eastern nation into a regional power with ambitious projects in a variety of sectors. In this framework, the government proceeded to legalize cinemas in 2018, with an unprecedented step of issuing seven licenses for major cinema operating businesses. All of the prominent steps designed to promote the film industry align with the broader concept of expanding Saudi Arabia's cultural and economic boundaries by adopting a path towards modernization and diversification. As the study seeks to investigate the social and economic prospects of the newly-established motion picture sector in the Kingdom of Saudi Arabia, the review is based on the recent commitments and current plans by Saudi authorities and associated organizations. From the socio-economic perspective, the decision to lift the ban on theatres is a crucial milestone, allowing the country to strengthen its entertainment sector. Despite the diversity of suggested strategic plans, the consensus of the Saudi authorities is to stimulate both local and foreign businesses seeking to open new cinemas in Riyadh, Jeddah, and other cities.
\end{abstract}

Keywords: Film industry, film growth, sustainable development, cinema, socio-economic scenario, socio-economic development, Saudi Arabia

\section{Introduction}

Throughout four decades between the early 1980s and late 2010s, the Kingdom of Saudi Arabia transformed from a developing Middle Eastern nation into a regional power with ambitious projects in a variety of sectors. The limitations associated with the predominant role of the petroleum industry prompted Saudi leadership to diversify and restructure the national economy, with a particular emphasis on the entertainment sector (Foley, 2019). With reference to the Islamic culture, film screenings contradict Arab cultural norms and religious beliefs, and therefore, the government imposed an overarching ban on all public cinemas across the country (Chulov, 2017). The consequent 35 years were marked with a complete cessation of all activities related to the film industry. As the Saudi government sought to explore options for socio-economic changes in the early 2000s and 2010s, the official revisited the idea of reopening cinemas in major urbanization centers such as Riyadh and Jeddah. Notably, the cinema ban was loosened on a handful of occasions to enable the demonstration of documentaries in the country's single IMAX theatre in Khobar and a hotel-owned cinema in Riyadh (Chulov, 2017). The imposed legal limitations did not deter Saudis from actively seeking alternatives such as satellite television, digital content, and online streaming services. To address both social and economic concerns, the Saudi leadership proposed a gradual re-opening of movie 
theatres as a part of the overarching Quality of Life Program 2020 (QoLP 2020). Signifying the beginning of a new era, Prince Mohamed Bin Salman announced a comprehensive plan to achieve Saudi Arabia's strategic and developmental goals in the scope of the Saudi Vision 2030 (Khan \& Iqbal, 2020). In this framework, the government proceeded to legalize cinemas in 2018, with an unprecedented step of issuing seven licenses for major cinema operating businesses (Pirani, 2018).

After opening new cinemas in Riyadh and Jeddah, the authorities further demonstrated their intention to advance economic and social spheres by addressing the expectations of the Saudi population. Specifically, the core principle of the Saudi Vision 2030 is to capitalize on the previously underexplored potential of industries not associated with the petroleum sector (Habibi, 2019). Despite the fact that only 2 years have passed after the opening of the first cinemas, Saudi Arabia's ambitious strategy managed to attract considerable international attention with major investments from both national and foreign businesses. In the context of QoLP 2020, the key priority is to establish a network of multiplex cinemas, offering the following screening formats: IMAX, Premium, Standard, 3D, 4D, and others (Oxford Business Group, 2018b). While benefiting from external investments, the country's leadership strengthened the prospects of the Saudi Vision 2030 by launching the Public Investment Fund (PIF). As the initiative with the capacity to complement the Saudi developmental framework, PIF identified the principal economic and cultural opportunities with the potential for commercial viability (Oxford Business Group, 2018a).

Finally, the relative scarcity of data on Saudi Arabia's film industry can be explained by the 35-year-long hiatus, preventing Saudi nationals from producing, screening, and watching films on the big screen. Between 1983 and 2018, there are nearly no physical records or references that would be beneficial to the scholarly analysis of the topic (Sar1, 2020). From the economic perspective, the research of Saudi Arabia's film industry is almost entirely limited to the reports produced after the lifting of the cinema ban in April 2018 (Chulov, 2017). As the study seeks to investigate the social and economic prospects of the newlyestablished motion picture sector in the Kingdom of Saudi Arabia, the review is based on the recent commitments and current plans by Saudi authorities and associated organizations.

\section{Study Scope and Objectives}

To accomplish the goal of assessing the socio-economic impacts of the motion picture industry in Saudi Arabia, the paper was subdivided into three major sections, each concerned with a separate aspect of the covered topic. Specifically, the first section establishes specific conceptual boundaries of the film industry from the perspectives of society, economy, and the industry's representatives. After elaborating on the channels of economic impact as evidenced by the examples of other countries, the authors proceed to explore the historical life cycle of cinema in different regions. On the other hand, the second section incorporates the ideas mentioned in the first section to construct a plausible overview of the industry's historical roles and projected impacts in Saudi Arabia. Drawing from previous precedents and analysing the proposed development plans, the authors explore the potential impacts of the motion picture sector from social and economic 
perspectives. Moreover, the second section includes a scenario forecast of the film industry's prospected value as a part of the entertainment sector of Saudi Arabia. Intended as a conclusive statement focusing on limitations and prospects, the third section summarizes the presented information and forms an outline of potential challenges and opportunities for the country's government and representatives of the film industry.

\section{Research Design and Methodology}

The study seeks to evaluate the potential socio-economic impacts of the newlyembraced cinema industry and estimate its value as a part of the entertainment sector. Specifically, the core research question guiding the study is "What is the socio-economic potential of the emerging film industry in Saudi Arabia?" Considering that an official reopening of cinema theatres in Saudi Arabia was in early 2018, there is no factual evidence regarding the direct economic impacts of the emerging sector. Preliminary research for topic-specific documents and reports revealed the absence of primary sources pertaining to ticket sales revenue, compound annual growth rate, the gross value in relation to the economy, and other crucial data. While the lack of publicly available information can be explained by the industry' novelty, the structure of governmental reports does not account for either entertainment or cinema industry as a separate category. Due to the inability to access reliable and continuous data sets, the authors based the descriptive and analytical processes on secondary sources, such as industry reports, indirect financial data, government-issued prospects, and others.

As a result of the aforementioned concerns, an appropriate research design should enable an in-depth overview of industry-specific and market-specific factors surrounding the emergence of the Saudi cinema industry. The collected evidence can be, consequently, used to analyze scarce data regarding the existing motion pictures market and planned expansion of the entertainment sector in the scope of Saudi Vision 2030. To address research objectives, the authors relied on the qualitative paradigm due to its unique potential for analyzing unstructured information originating from unrelated sources (O'Reilly \& Kiyimba, 2015). In this framework, a systematic literature review and scenario analysis were employed to facilitate the research process by relying on descriptive and analytical methods. Guided by the research questions, the authors performed exhaustive research of literature in Arabic and English to identify relevant trends, inputs, or other evidence pointing to the impacts of the film industry in Saudi Arabia. Consequently, the results pertaining to socio-economic roles of the film industry in Saudi Arabia were used as a basis for the scenario forecast intended to create a plausible estimation for the sector's development in the upcoming decade (Kosow \& Gaßner, 2008). Considering methodological decisions, the aforementioned factors necessitated the adoption of a qualitative approach with collected data serving as a basis for the scenario analysis.

Taking into account specific characteristics of collected information, quantitative types of forecasting research were deemed inadequate. Namely, all financial reports concerned with the film industry in Saudi Arabia are limited to predictions and scarce reports. Apart from brief mentions of actual ticket sales in late 2019 and 2020, sources are limited to speculative estimations or industry-wide projections for Saudi Vision 2030. Importantly, the investigation did not reveal any evidence regarding the industry's financial performance in 
2018 and early 2019. Considering the absence of a data set containing more than a dozen data points, formal methods of forecasting would have been increasingly uncertain due to the high prediction error (Montgomery et al., 2015). Time series regression model and other forecasting methods were rejected as the research did not meet data requirements. With ARIMA, exponential smoothing, and grey models requiring more than ten data points for a relatively short time horizon of prediction, the authors concluded that scenario analysis would be the most suitable analytical approach (Montgomery et al., 2015). After identifying the field of study and selecting relevant key factors, the researchers performed analysis and scenario generation to construct a plausible model for the film industry's socio-economic impacts (Kosow \& Gaßner, 2008). Finally, by comparing and contrasting the forecasted scenario with official projections by the Saudi government and experts, the obtained results were used to form a plausible hypothesis and answer the research question.

\section{Overview of the Global Film Industry}

The film industry is a relatively broad term encompassing processes that are directly and indirectly related to movie production and screening. As individual identification of all film-related activities is unfeasible and out of the scope of this research, the chosen approach facilitates the consequent analysis of economic and social impacts. Taking into consideration the lack of historical data regarding the emerging motion picture industry and associated markets in Saudi Arabia, the overview of the global film industry can provide evidence for the consequent analysis and projections. From this standpoint, the study is conducted with a full appreciation of different elements of film production and film screening, with additional regard for regional specifics. This approach provides an opportunity for extrapolating observations on the situation in Saudi Arabia and forming specific conclusions regarding the socio-economic importance of the emerging industry. To ensure concordance with reports and studies focusing on this topic, the paper relies on industry-specific terminologies that will be explained below.

Film production: IP rights; pre-production; planning, writing, direction, and casting; location, equipment rental, staffing; filming, camera operations, sound recording, mixing, animation, and visual effects; and post-production including editing, music, sound, and post-production computer-generated imagery (CGI).

Distribution: film duplication; secondary distribution of digital or physical content (DVD, digital storage, TV sales, online, and others).

Exhibition: cinema distribution; screenings; festival screenings (Ginsberg \& Lippard, 2020).

\section{The Channels of Economic Impact}

With authors adopting different approaches for assessing the contributions of the film industry, the latter can be categorized into four principal channels of impact. The latter include cultural impact, direct impact, indirect impact, and induced impact. Regardless of specific outcomes, each category broadly defines a set of standard contributions associated with the movie industry. Both broad definitions and specific 
examples are elaborated below.

\section{Direct Impact}

Pre-eminently concerned with economic outcomes, this channel typically involves financial output and job employment as a result of direct business activities associated with the television and film sectors (Ginsberg \& Lippard, 2020).

\section{Indirect impact}

In contrast to direct impact, this channel covers output and employments arising from businesses indirectly associated with the film and television sectors. The involvement of third parties is a common practice in the industry and can be outlined with the following examples: market research, real estate services, travel, electronic machinery, electricity, and others (Ginsberg \& Lippard, 2020).

\section{Induced impact}

Deriving from the previous two categories, induced impact encompasses output and employment associated with financial operations which are not explicitly related to the film industry. However, direct and indirect contributions of the film and TV sectors provide the capital in form of wages for spending in other economic spheres (Ginsberg \& Lippard, 2020). In this case, the key examples of sectors benefiting from induced impact are the following: recreational, entertainment, retail, food production, agriculture, textile manufacturing.

\section{Cultural Impact}

As opposed to political programs and governmental operations, films carry the capacity to initiate transformations leading to changes to one's worldview and understanding (Khan \& Iqbal, 2020). Apart from immediate outcomes, films can induce a variety of changes to a person's life as the former to fulfill the following roles: broadening knowledge, sending meaningful messages, develop societal behaviors, and others (Sar1, 2020). The chosen perspective provides a basis for estimating the expected economic contributions of individual Saudis to the film industry in particular and the nation as a whole.

\section{Integrative Roles in Society}

Comprising of commercial and technological constituents, film-making carries the propensity for connecting multilingual and multicultural groups of people engaged in the following operations: pre-production, production, post-production, screenwriting, animation, cinematography, festival organization, distribution, directing, acting, and others (Ginsberg \& Lippard, 2020). While all experts involved in the defined processes dedicate their energy towards a common goal, the film industry can breach cultural, religious, and political boundaries. From the economic perspective, the worldwide theatrical market continues to expand by encompassing increasingly more diverse population groups. As cinema-goers across the world contribute to the sector's growth, the figures for 2016 can provide an outlook of the film industry's scope - total box office is $\$ 38.6$ billion; the AsiaPacific region is $\$ 14.9$ billion; the North American region is $\$ 11.4$ billion; and the Middle East, North Africa, and Europe combined is $\$ 9.5$ billion. 


\section{Economics of the Film Industry}

The profitability of a film-making business or film studio depends on the choice of produced motion pictures, managerial and administrative decisions, and creative work (Vogel, 2020). From another perspective, the economic outcome is tied to the scale and depth of promotional efforts in relation to the expected target audience. Although intellectual property and associated licensing efforts can considerably increase revenues, the overall economic outcome can be improved with the help of careful planning (Pirani, 2018). Nevertheless, the reception by cinema-goers is a final contributor to the final gains of a movie studio.

From the global perspective, economists suggest that the market price of energy sources plays an integral role in price formation as concerned with the entertainment sector and media industries. While particularly relevant to Saudi Arabia, the analytical data indicates that personal consumption expenditure comprises a multitude of variables. Nevertheless, the financial reports demonstrate that the film industry has considerably expanded since 2005 due to the growth of regional markets (Deloitte, 2020). The film and television industry has grown strongly since 2005 although progress has been volatile. As evidenced by the example of South Korea, both television and film sectors contributed to the increase of GDP by $84 \%$, or $10.7 \%$ annually throughout the period between 2005 and 2011 (UNESCO, 2016). However, the same source claims that employment growth lagged behind with 1.4\% annually, when considering the labor involved in product creation.

The data for other countries is provided by UIS and accounts for the financial growth amounted to box office receipts. Between 2012 and 2013, the global growth neared 5\%, which corresponds to $\$ 26.9$ billion at the end of the last quarter of 2013 (UNESCO, 2016). Accounting the box office receipts worldwide, the major markets for the film industry are the following: Australia, South Korea, Russia, the U.S., China, Japan, the U.K., Germany, and India (Vogel, 2020).

When considering expansion rates, China emerges as the most illustrative example in the early twenty-first century. Specifically, revenues associated with the movie sector approached $\$ 244$ million in 2005 , as the country opened its markets to foreign countries. In contrast, total revenues approached $\$ 3.6$ billion by 2013 , which accounts for more than ten-fold growth. In comparison to China, box office sales in the U.S. have not significantly changed for the past three decades (Deloitte, 2020). If the tendency continues in the 2020s, the former is likely to outpace the latter as revenues in the industry become increasingly higher. Interestingly, India's film industry is comparatively small and would be dwarfed by a single Hollywood title such as Titanic or Avatar. According to the analysts, Bollywood is a sector worth $\$ 2$ billion with the factual estimated capitalization of $\$ 10$ billion (Tripathi, 2017).

As one of the key economic factors, the average ticket price can be used to infer the overall potential for continuous expansion and growth. While the global average figure for 2013 amounted to $\$ 7.10$, the price in Senegal cinemas was $\$ 0.56$, which is significantly lower than $\$ 17.48$ in Bahrain (UNESCO, 2016). Due to the complexity of estimating the economic contributions of the motion picture industry, a film's budget is often used as an indicator allowing to approximately infer other variables (Deloitte, 2020). Notably, the total cost of film production is expected to encompass most of the associated expenses 
such as actors' wages, logistics, costs of special effects, and others.

Table 1. Largest markets by gross box office (UNESCO, 2016).

\begin{tabular}{|c|c|c|c|c|c|}
\hline Rank & Country & $\begin{array}{l}\text { Gross box office } \\
\text { (billions in US\$) }\end{array}$ & $\begin{array}{l}\text { Average ticket } \\
\text { price (in US\$) }\end{array}$ & $\begin{array}{c}\text { GDP } \\
\text { per capita }\end{array}$ & $\begin{array}{l}\text { Population } \\
\text { (in million) }\end{array}$ \\
\hline 1 & United States & 10.9 & 8.10 & 51,749 & 355.1 \\
\hline 2 & China & 3.6 & 5.74 & 6,091 & 1,385 \\
\hline 3 & Japan & 2.4 & 12.77 & 46,720 & 127 \\
\hline 4 & United Kingdom & 1.7 & 10.9 & 39,093 & 63.1 \\
\hline 5 & France & 1.6 & 8.57 & 39,772 & 64.3 \\
\hline 6 & India & 1.5 & 0.81 & 1,489 & 1,252 \\
\hline 7 & South Korea & 1.4 & 6.64 & 22,590 & 49.2 \\
\hline 8 & Russia & 1.4 & 7.55 & 14,037 & 142.8 \\
\hline 9 & Germany & 1.3 & 10.71 & 41,863 & 82.7 \\
\hline 10 & Australia & 1.1 & 12.95 & 67,556 & 23.3 \\
\hline
\end{tabular}

Due to the inability to obtain data for film production in Saudi Arabia, the primary indicator is the projected cost of opening new cinemas in the country. According to the VOX Cinemas, the corporation expects to construct and launch 600 theatres across the nation in a span of 5 years (Vivarelli, 2018). The planned venture is associated with a considerable monetary commitment, as VOX Cinemas has pledged \$533 million towards this endeavor (Oxford Business Group, 2018b). On the other hand, Cinépolis has gradually initiated the process of launching cinemas across the largest population centers of Saudi Arabia, with 63 operating theatres in Jazan, Jeddah, Riyadh, Najran, and Dammam. In the scope of the Saudi Vision 2030, Saudi Arabia will have the capacity to operate 2,600 cinemas in the upcoming 2 decades. The review by PwC Middle East elaborates on this claim by suggesting that the growing interest of Saudis will fuel the total financial contribution of the film industry to the country's economy (PwC Middle East, 2020). For instance, the Indian media and entertainment (M\&E) industry is estimated at INR $126 \mathrm{~K}$ crore (US\$19.4 bn) i.e. 1\% of India's GDP. However, this makes the sector larger than India's consumer durables and online retail industries.

Table 2. Largest markets by box office revenues (UNESCO, 2016).

\begin{tabular}{|c|l|c|c|c|}
\hline \multirow{2}{*}{ Rank } & \multirow{2}{*}{ Country } & Box office revenue & Box office from & \multirow{2}{*}{ Year } \\
\cline { 3 - 4 } & & (billion US\$) & National films (in \%) & \\
\hline N/A & World & 41.7 & N/A & 2018 \\
\hline 1 & United States & 11.08 & $88.8 \%(2015)$ & 2018 \\
\hline 2 & China & 9.15 & $82 \%(2018)$ & 2018 \\
\hline 3 & India & 2.44 & $54.4 \%(2019)$ & 2018 \\
\hline 4 & Japan & 2.39 & $44.3 \%(2017)$ & 2018 \\
\hline 5 & United Kingdom & 1.72 & $52.2 \%(2015)$ & 2017 \\
\hline 6 & South Korea & 1.6 & $36.2 \%(2017)$ & 2018 \\
\hline 7 & France & 1.5 & $26.3 \%(2017)$ & 2018 \\
\hline 8 & Germany & 1.11 & $17.4 \%(2015)$ & 2017 \\
\hline 9 & Russia & 1 & $4.1 \%(2017)$ & 2018 \\
\hline 10 & Australia & 0.95 & & \\
\hline
\end{tabular}




\begin{tabular}{|c|l|c|c|c|}
\hline \multirow{2}{*}{ Rank } & \multirow{2}{*}{ Country } & Box office revenue & Box office from & \multirow{2}{*}{ Year } \\
\cline { 3 - 4 } & & (billion US\$) & National films (in \%) & \\
\hline 11 & Brazil & 0.9 & $8.9 \%(2017)$ & 2017 \\
\hline 12 & Mexico & 0.87 & $6.6 \%(2017)$ & 2018 \\
\hline 13 & Canada & 0.76 & $3.2 \%(2017)$ & 2017 \\
\hline 14 & Spain & 0.7 & $17.4 \%(2017)$ & 2017 \\
\hline 15 & Italy & 0.7 & $17.6 \%(2017)$ & 2017 \\
\hline
\end{tabular}

While the individual breakdown of box office revenue illustrates the disparity between different countries, the total value of the global box office approached $\$ 41.7$ billion by 2018. Together with home entertainment, the box office can be used to calculate the estimated worth of the global motion picture industry - \$136 billion (IBISWorld, 2019).

Table 3. Largest industries by number of film productions (IBISWorld, 2019).

\begin{tabular}{|c|c|c|c|}
\hline Rank & Year & Films & Country \\
\hline 1 & 2018 & 1,813 & India \\
\hline 2 & 2011 & 997 & Nigeria \\
\hline 3 & 2017 & 874 & Japan \\
\hline 4 & 2019 & 689 & United States \\
\hline 5 & 2017 & 660 & South Korea \\
\hline 6 & 2016 & 339 & France \\
\hline 7 & 2017 & 300 & United Kingdom \\
\hline 8 & 2017 & 285 & Spain \\
\hline 9 & 2017 & 241 & Argentina \\
\hline 10 & 2017 & 233 & Mexico \\
\hline 11 & 2015 & 220 & Italy \\
\hline 12 & 2017 & 176 & Brazil \\
\hline 13 & 2017 & 173 & Turkey \\
\hline 14 & 2017 & 160 & \\
\hline 15 & 2017 & 148 & \\
\hline
\end{tabular}

Compiled with the use of data by the UNESCO Institute of Statistics, the list of feature films by country includes documentaries, fiction, and animation titles. Sorted by yearly production, the list demonstrated that India maintains the largest production capacity for filmmaking in the world. In 2018, Bollywood released 1813 feature films, which equals the combined figure for the second and third contenders - Nigeria and China, respectively (Ruus \& Sharma, 2019).

\section{Overview of Regional Film Industries}

\subsection{Bollywood}

With the center in Mumbai, India, Bollywood can be considered as one of the most productive film industries worldwide, with the predominant production capacity being located across India. Primarily focused on the Hindi-speaking audience, Bollywood is a constituent part of the larger Indian movie sector comprising of numerous non-Hindi studios (Ruus \& Sharma, 2019). Following the rise of Indian cinematography between 
1940 and 1960, Hindi cinema was established as one of the defining cultural elements of the entire country (Tripathi, 2017).

\subsection{Hollywood}

Originating in 1911 with a small film production facility, Hollywood rapidly expanded from the times of $\mathrm{Al}$ Christie and David Horsley. Across the larger Hollywood area, five notable studios rose to prominence throughout the 1930s - RKO, Warner Bros, Metro-Goldwyn-Mayer, Paramount, and 20th Century Fox. Following the pervasive expansion of the television industry in the 1950s, the largest film studios adopted a combined approach to produce both feature films as well as the content for other media (Ruus \& Sharma, 2019). In the twenty-first century, Hollywood remains the filmmaking center attracting industry experts from across the globe.

\subsection{Cinema Industry in the Middle East}

Both Pathé Frères and Lumière Brothers contributed to the initial establishment of cinematography in the Arab countries in the early twentieth century (Shafik, 2007). In the early 1950s, Egypt emerged as one of the most prominent centers of filmmaking in the region, prompting many Middle Eastern countries to adapt Egyptian conventions for producing films intended for the Arab-speaking audience (Foley, 2019). In the twenty-first century, industry figures from across the world have focused on the Middle East and North Africa region as the prospective market for filmmaking as well as the source of talented professionals. Predominantly filmed in the region, the following Hollywood feature films have received worldwide acclamation in recent years: The Kingdom, Syriana, The Hurt Locker, In the V alley of Elah, and Transformers: Revenge of the Fallen (Messnaoui, 2014).

\subsection{Egypt}

With the conclusion of World War II, Egypt's cinematography attracted everincreasing attention from both industry enthusiasts and investors. The possibility of raising more than 100,000 Egyptian pounds with average expenses of 20,000 to 25,000 EGP stimulated the consequent development of the Arabic cinematography (Shafik, 2007). Throughout the entire period between 1945 and 1951, local studios release 341 feature film or 50 individual titles annually (Messnaoui, 2014). The industry's impact on society and economy is especially evident in the 1950s and the early 1960s, as the Revolution of 1952 provided soil for new modes of artistic expression. While the annual film production exceeded 60 by 1952, the country's network of cinemas gradually expanded to 354 independent motion theatres (Messnaoui, 2014). To account for an overarching cultural impact of cinematography, Egypt's government had established the Arts Department and the Film Support Foundation to promote the production of short films, documentaries, and others (Shafik, 2007). Throughout the second half of the twentieth century, the industry's growth decelerates, prompting local artists and filmmakers to develop novel approaches and technical solutions.

\subsection{Morocco and Tunisia}

In the Maghreb region, Morocco and Tunisia can be considered as prominent examples of North African cinema intended for the Arab-speaking audience. Merging both 
Western and Egyptian approaches to cinematography, local filmmakers benefit from the close ties with their European counterparts. Specifically, Morocco's economy receives between $\$ 50$ and 70 million each year from international cooperations with foreign film studios (Messnaoui, 2014). Due to low labor cost and vibrant cultural landscape, two North African nations emerge as increasingly attractive options or Western studios.

\subsection{Dubai Media City}

However, the most striking example of Arabic filmmaking is the United Arab Emirates, as the country hosts five major media cities. Among the local industry clusters, the Dubai Media City (DMC) can be singled out due to its immense cultural and financial prospects (Mould, 2016). Dwarfing the successes of other countries in the Middle Eastern region, DMC was established as a subsidiary of Dubai Holding by TECOM Investments in 2001. While the overall ownership of the company can be attributed to Sheikh Mohamed bin Rashid Al Maktoum, DMC aims to revolutionize telecommunication and IT sectors in the Arab-speaking world (Martin et al., 2016). Finally, extensive support from the government facilitates the launch of the Dubai Studio City, a competing film production facility with nearly limitless resources and filmmaking capacity.

\subsection{Saudi Cinema}

For more than three decades, the Saudi population had been prevented from visiting cinemas without traveling to neighboring Qatar or the UAE. However, the 35-year ban suppressing the entire film industry had been overturned by the decision of the Kingdom's authorities in 2018 (Chulov, 2017). The government initiated the process in 2016 with the creation of the General Authority for Entertainment, a body tasked with the enhancement of the entire entertainment industry. Following the announcement by $\mathrm{Al}$ Madani in January 2017, the citizenry was expecting an upcoming re-opening of cinemas across Saudi Arabia (Mould, 2016). Less than one year later, the Saudi authorities successfully initiated the program to reignite the spheres of cinematography and filmmaking.

From the historical perspective, the development of the motion pictures industry in Saudi Arabia mirrored the paths of other Middle Eastern and even European countries. Similar to the launch of cinemas for Arab-speaking audience in Egypt, Saudi Arabia's film sector emerged in the early 1930s. Interestingly, the first cinema screenings were presented to expatriate employees of the California Arab Standard Oil Company (currently known as Aramco) (Ginsberg \& Lippard, 2020). While the latter could indulge in cinematography, Aramco funded a series of culturally significant documentaries, such as the opening of the first oil drill with the attendance of King Abdulaziz bin Abdulrahman Al Saud.

Despite the growing popularity of cinema in the later 1970s, the government resorted to banning this activity due to its perceived imprudence and inappropriateness. Apart from occasional screenings by private companies, the entire industry continued to lay dormant for nearly three decades (Jarjoura, 2014). Nevertheless, a handful of Saudi enthusiasts produced and shot feature films in the neighboring countries, with the notable examples being Keif-al-Hal?, Wadjda, and Barakah Yoqabil Barakah (Sar1, 2020). The shifting public sentiment and economic necessity prompted the Saudi leadership to reconsider its stance on cinematography. As the reopening of cinemas initially affected commercial centers of 
Riyadh and Jeddah, observes immediately noted a particularly high demand among the Saudi population. According to cinematography enthusiasts in the country, many talented filmmakers are hampered by the lacking or virtually absent infrastructure in the movie industry (Foley, 2019). In this framework, the government and private investors are ought to prioritize the sectors as one of the key means for diversifying Saudi Arabia's economy and promoting Saudi culture.

\section{Saudi Vision}

As implemented under the guidance of King Salman bin Abdulaziz and Crown Prince Mohammed bin Salman, the underlying purposes of the Saudi Vision 2030 align with the long-term goals of the country's film industry. Specifically, the decision to diversify the economic sectors by prioritizing recreation and entertainment can be achieved with the concerted efforts of filmmakers, investors, and the Saudi authorities (Habibi, 2019). In this framework, the Saudi Broadcasting and Visual Media Authority spearheaded the transformation of the motion pictures industry by granting the approval for issuing cinema licenses for businesses seeking to invest in Saudi Arabian markets. In the scope of the QoLP 2020, the Minister of Culture and Information informed the population that the re-opening of cinemas in 2018 is merely the first step towards flourishing Saudi cinematography (Oxford Business Group, 2018b; Pirani, 2018). Finally, the Saudi Vision 2030 sets a bold goal of opening at least 300 theatres in more than ten Saudi cities by 2030. Approximately 2,000 screens of different audience capacity are expected to accommodate the ever-growing demand for new Arabic and foreign feature films by 2030 (Oxford Business Group, 2018a).

As planned in the scope of Saudi Vision 2030, the construction of new cinema complexes across the country will be undertaken in a gradual manner by attracting public and private investors. With Development Investment Entertainment Company pledging 1 billion SAR and other contributors either directly or indirectly investing in the venture, the total number of cinemas will exceed 45 by the end of 2020. Importantly, the QoLP 2020 served as a catalyst for the market's growth by attracting major players such as VOX Cinemas, PVR Limited, Cinepolis, and others (Quality of Life Program, n.d.). Considering that the country's population will exceed 39 million by 2030, the Saudi agency estimated that 2,600 screens or 370 cinemas will be necessary to satisfy the growing demand. Nevertheless, the QoLP ambitiously aims to increase out-of-home entertainment spending by attracting more than 3,6 million cinema-goers by the end of 2020 (PwC Middle East, 2020). The QoLP 2020 mentions that the reopening of cinemas will prove instrumental for developing a national filmmaking industry and promoting cultural values and traditions of Saudi Arabia.

\section{Economic Impact of the Film Industry in Saudi Arabia}

While the lack of current data for Saudi Arabia makes the calculation of induced and cultural impacts unfeasible and cumbersome, the paper will focus on both direct and indirect economic contributions. Notably, the majority of used data pertain to long-term projections within the scope of Saudi Vision 2030. Apart from sporadic seances organized 
in the early 2000s and 2010s, Saudi Arabia's motion pictures sector was non-existent for three decades (Chulov, 2017). As a result, the initial economic analysis can be exclusively based on strategic plans and industry reports published between 2018 and 2020. The first indicators of the film industry's impact on the country's economy emerge in 2020 as a part of the presentation at the META Cinema Forum (Vivarelli, 2020). Unfortunately, the data is largely non-representative of the sector's actual value as well as the popular demand due to the closure of cinemas as a part of anti-pandemic measures. From the early spring to late summer 2020, the spread of COVID-19 prompted the Saudi government to completely close all cinemas across the country. By autumn 2020, anti-pandemic measures were partially lifted as the government allowed cinemas to operate at a $20 \%$ occupancy rate (Lakhpatwala, 2020). From this perspective, most economic estimations will be highly unreliable and situative as the pandemic affected the performance of most industries in Saudi Arabia and surrounding countries.

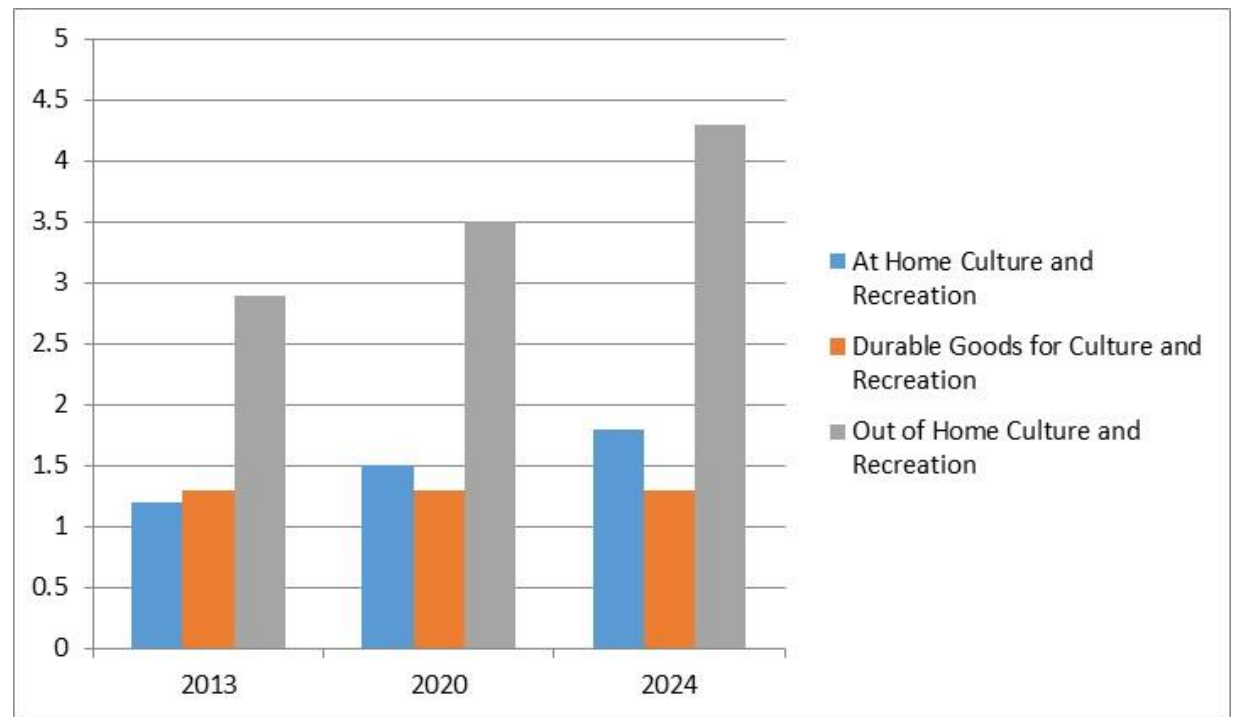

Figure 1. Growth of out of home entertainment sectors (in \%) (UNESCO, 2016).

\subsection{Direct Impact}

With billions of dollars being invested to open new cinemas and establish a filmmaking production capacity in Saudi Arabia, the financial contributions are dispersed across the industry, involving businesses with both primary and secondary functions. In this context, there is no evidence of film studios operating from Saudi Arabia at full capacity (Vivarelli, 2018). Accordingly, it is impossible to calculate the direct impact of the filmmaking process on the country's economy, apart from the projected $\$ 533$ million pledge by VOX Cinemas and the 1 billion SAR investment by DIEC (Oxford Business Group, 2018a). According to Saudi Arabia's statistic for 2019, 24,308 individuals were employed in sectors related to the film industry by the end of the third quarter of 2019. Overall, the key goal of Saudi Vision 2030 is to stimulate the country's filmmaking industry and create employment opportunities for directors, actors, and others. 
To encourage private businesses, the government adopted a set of supportive measures, such as financial support, fiscal support, and employment support (Khan \& Iqbal, 2020). Specifically, credit financing and loan programs are being developed to accommodate the needs of growing entertainment companies in Saudi Arabia. As 58\% of Saudis are under the age of 35, the establishment of the Qiddiya site near Riyadh is expected to attract millions of visitors annually in the upcoming decades. Due to the high purchasing power of the nation's citizens, ticketed events such as movie screenings can serve as an important driver of the recreation sector (Habibi, 2019). Finally, the adoption of the Saudi Vision 2030 initiative envisions the consequent start-up of new processes and organizations.

Table 4. The comparative illustration of proposed initiatives and expected outcomes (Kingdom of Saudi Arabia, 2020).

\begin{tabular}{|c|c|}
\hline Initiative & Impact \\
\hline $\begin{array}{l}\text { Accelerate the growth of } \\
\text { entertainment businesses and } \\
\text { projects }\end{array}$ & $\begin{array}{l}\text { - Training will be offered for the qualified participants to assist } \\
\text { in launching entertainment projects ( } 70 \text { beneficiaries by } 2020 \text { ) } \\
\text { - The plan involves at least } 2 \text { annual launches of entertainment } \\
\text { programs in the region }\end{array}$ \\
\hline \multirow{3}{*}{$\begin{array}{l}\text { Focus on innovation and } \\
\text { development centers for the } \\
\text { purposes of the entertainment } \\
\text { sector }\end{array}$} & $\begin{array}{l}\text { - Opening } 3 \text { youth-oriented innovation facilities by } 2020 \\
\text { (Jeddah, Dammam, Riyadh) }\end{array}$ \\
\hline & $\begin{array}{l}\text { - Promoting local content production with a focus on cultural } \\
\text { development }\end{array}$ \\
\hline & $\begin{array}{l}\text { - Establishing awards for accomplishments and entertainment } \\
\text { innovations }\end{array}$ \\
\hline \multirow{3}{*}{$\begin{array}{l}\text { Promote Saudi-based } \\
\text { entertainment solution to } \\
\text { foreign visitors }\end{array}$} & $\begin{array}{l}\text { - By the end of 2020, } 75 \text { million SAR will be used to finance } \\
\text { advertisement campaigns of original Saudi content }\end{array}$ \\
\hline & $\begin{array}{l}\text { - Prioritizing the marketing efforts for promoting locally-made } \\
\text { content in foreign countries }\end{array}$ \\
\hline & $\begin{array}{l}\text { - Encouraging Saudi talents and professional to seek } \\
\text { employment in the entertainment sector across the country }\end{array}$ \\
\hline
\end{tabular}

\subsection{Direct Contribution to the GDP}

With the partnership of Cinema Build KSA 2020, the Great Minds Group conducted and published market research of the newly-established cinema sector in Saudi Arabia. According to the report, the total investments in filmmaking and cinema initiatives will exceed 5 billion SAR by the end of 2020 (PwC Middle East, 2020). Among the immediate outcomes will be the expected launch of 140 theatres in 30 different malls across the largest cities. In the scope of the 5-year plan, DIEC pledged to construct at least 40 cinemas across 15 cities. Similarly, Majid Al Futtaim Cinemas published a plan to annually invest $\$ 100$ million in Saudi Arabia's film sector to open more than 600 new screens in the upcoming five-year-period (Khan \& Khan, 2020). The ambitious claim is a part of the larger investment program with a budget of 2 billion SAR. Requiring more than $\$ 70$ billion to achieve its goals, the ambitious project will be funded with the help of yearly instalments varying between $\$ 4$ billion and $\$ 6$ billion (PwC Middle East, 2020). Considering all contributions and pledges made by investors, the project's organizers anticipate the construction of over 350 cinemas by 2030 . 
The reported growth of Saudi Arabia's entertainment industry has reportedly reached $18,960,862$ Saudi riyals in 2016, with enterprise revenues amounting to 2,706,671 riyals. As the same indicator had grown to 17,379,336 in 2017, the projected figures for 2019 and 2020 are 20,686,307 riyals and 22,568,767 riyals, respectively (Al-Jazirah, 2019). As evident by the stable expansion of different sectors, the film industry is likely to contribute to the overall growth of Saudi Arabia's economy. While the total employment figures for 2016 and 2017 were 1325 and 1382, respectively, the film industry is projected to contribute no less than 90 billion SAR as both direct and indirect impact (Al-Jazirah, 2019). Although the presented data indicates stable growth of the entire recreational services industry, there are no publicly accessible reports regarding the value added by the cinema sector, in particular.

Table 5. The entertainment sector's financial and industry-specific indicators for the period between 2016 and 2020 (Al-Jazirah, 2019).

\begin{tabular}{|l|c|c|c|c|c|}
\hline & $\mathbf{2 0 1 6}$ & $\mathbf{2 0 1 7}$ & $\mathbf{2 0 1 8}$ & $\begin{array}{c}\mathbf{2 0 1 9} \\
\text { (Projected) }\end{array}$ & $\begin{array}{c}\mathbf{2 0 2 0} \\
\text { (Projected) }\end{array}$ \\
\hline $\begin{array}{l}\text { Total value added for the } \\
\text { entertainment sector (million SAR) }\end{array}$ & $1,433,178$ & $9,754,919$ & $10,418,253$ & $11,126,694$ & $11,883,309$ \\
\hline $\begin{array}{l}\text { The number of jobs in the } \\
\text { entertainment sector }\end{array}$ & 16,166 & 160,790 & 170,598 & 181,004 & 192,045 \\
\hline $\begin{array}{l}\text { The number of jobs reserved for Saudi } \\
\text { nationals }\end{array}$ & 6,858 & 45,825 & 49,303 & 52,853 & 56,845 \\
\hline The proportion of Saudis employed & $47 \%$ & $40 \%$ & $41 \%$ & $42 \%$ & $43 \%$ \\
\hline
\end{tabular}

Table 6. Private final consumption expenditure in the domestic market by the purpose of expenditure at constant prices (Al-Jazirah, 2019).

\begin{tabular}{|l|c|c|c|c|c|}
\hline & 2013 & 2014 & 2015 & $\begin{array}{c}2016 \\
\text { (Projected) }\end{array}$ & $\begin{array}{c}2017 \\
\text { (Projected) }\end{array}$ \\
\hline Final consumption expenditure (million SAR) & 88,685 & 92,189 & 101,967 & 106,667 & 105,157 \\
\hline
\end{tabular}

\subsection{Infrastructure}

Considering the overarching scope of the QoLP 2020 program, the government strongly encourages businesses to fill the existing gap in various industries and sectors such as recreation, filmmaking, and others (Khan \& Iqbal, 2020). The current lack of theatre and cinema infrastructure provides a major opportunity for local entrepreneurs and investors, seeking to expand their portfolio and enter new markets. In this context, Cinema Build KSA Forum spearheads the development of cinema-related infrastructure with cooperation with both local and foreign organizations. By the end of 2020, the lowest goal is to open 45 theatres, including IMAX, Multiplex, and others (Khan \& Khan, 2020). The aforementioned expectations strikingly contrast with a relatively stable radio and TV segments, as well as theatre shows in Saudi Arabia.

Table 7. Radio and TV channels in K.S.A. (Statista Research Department, 2017).

\begin{tabular}{|l|c|c|c|c|c|}
\hline & 2014 & 2015 & 2016 & 2017 & 2018 \\
\hline National TV Channels (landed and Space) & 23 & 23 & 17 & 17 & 16 \\
\hline National TV Channels (landed and Space) through Internet & 17 & 17 & 9 & 9 & 9 \\
\hline
\end{tabular}


Radio Channels (landed and Space)

Radio Channels (landed and + Space) through Internet

\begin{tabular}{|l|l|l|l|l|}
\hline 11 & 11 & 11 & 11 & 11 \\
\hline 12 & 12 & 12 & 12 & 12 \\
\hline
\end{tabular}

Table 8. Theatres and shows in K.S.A (Althaqeel, 2017).

\begin{tabular}{|l|c|c|c|c|c|}
\hline & 2014 & 2015 & 2016 & 2017 & 2018 (projected) \\
\hline Theatres & 35 & 35 & 35 & 35 & 35 \\
\hline Theatres show & 46 & 53 & 55 & 55 & 55 \\
\hline Concerts on stages & 10 & 9 & 13 & 23 & 0 \\
\hline
\end{tabular}

\section{Scenario Analysis}

The reports on the value added to the entertainment sector are not representative of the cinema sub-sector and cannot be used to extrapolate the latter's impact on the country's economy. Similar to most quantitative forecasting techniques, both ARIMA and exponential smoothing time series models do not apply to data sets containing a small number of data points (Montgomery et al., 2015). To avoid potential problems with low accuracy due to inadequate variance of prediction errors, the authors followed the scenario forecasting process. Focusing on the socio-economic impacts of the cinema industry, the following factors allowed to generate a plausible outcome: ticket sales in 2019 and 2020, the projected growth of out-of-home entertainment, and industry-specific estimations published by experts. As evidenced by direct socio-economic contributions discussed in previous chapters, the number of operating cinemas is expected to reach 45 by 2020 . However, the spread of COVID-19 and associated social distancing measures had a substantial impact on the cinema industry, in particular, and the entertainment sector, in general. With cinemas being closed for nearly three months in 2020 and capacity limits being introduced in the consequent period, the forecasted value is likely to be lower than was initially planned (Lakhpatwala, 2020).

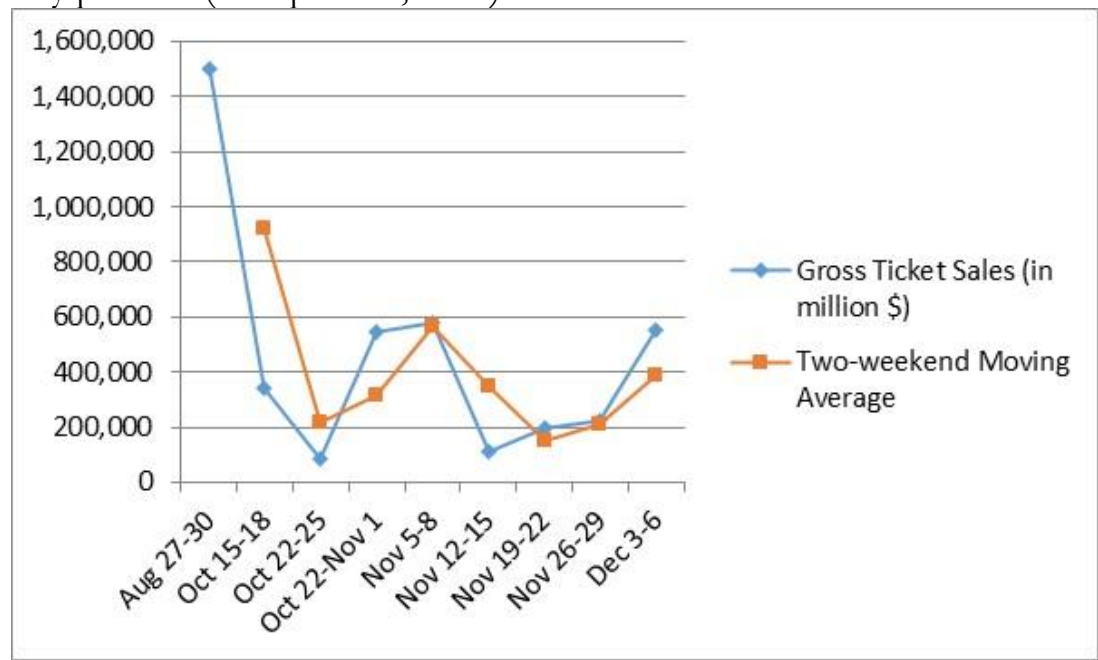

Figure 2. Time series projection for gross ticket sales during the nine-weekend period. Data set from Box Office Mojo (2020). 
The analysis of Saudi box office revenues during nine weekends between August and December reveals high variance and considerably reduced figures in comparison to ticket sales recorded in the first months of 2020 (Box Office Mojo, 2020). A time-series moving average decomposition is relatively uninformative because the fluctuations reflect antipandemic measures. Specifically, the maximum occupancy of cinemas across Saudi Arabia was limited at $20 \%$ throughout the entire observed period. The report presented during the META Cinema Forum provides an opportunity to compare ticket sales in 2019 and 2020 (Vivarelli, 2020). Reaching nearly $\$ 110$ million in ticket sales in 2019, Saudi cinema market is forecasted to grow during 2020. In spite of the pandemic, the forecast suggests that the total box office will exceed $\$ 120$ million which amounts to approximately 8\% annual growth. While the QoLP 2020 goal was accomplished with the construction of 614 screens, only 260 screens operated throughout 2020. According to the latest estimations, the pandemic will not halt the opening of new cinemas as experts claim that 340 and 700 screens will be in operation by the end of 2020 and 2021, respectively (Vivarelli, 2020). Due to the fact that ticket prices in Saudi cinemas reach $\$ 17$ and the demand remains high, the cinema industry is expected to continue growing in the upcoming years.

\section{Conclusion}

In the light of the recent re-opening of cinemas in Saudi Arabia, the Saudi leadership demonstrates its dedication to the goals of the QoLP 2020 and the overarching Saudi Vision 2030. While the 35-year ban had a negative impact on the film industry in the Middle Eastern country, the experiences of other Arabic nations suggest that filmmaking can be considered as a valuable contributor to the economy and culture (Habibi, 2019). From the socio-economic perspective, the decision to lift the ban on theatres is a crucial milestone, allowing the country to strengthen its entertainment sector. Despite the diversity of suggested strategic plans, the consensus of the Saudi authorities is to stimulate both local and foreign businesses seeking to open new cinemas in Riyadh, Jeddah, and other cities.

Unfortunately, the lack of data for the period between 1983 and 2018 presents certain challenges to the accurate estimation of the economic and social impacts of the film industry. By extrapolating evidence from regional filmmaking hubs such as the UAE and Egypt, it is possible to assume that the upcoming decade will transform Saudi Arabia's cultural landscape (Martin et al., 2016). Furthermore, the proposed investment plans as well as the ongoing programs contribute to the economy by providing new jobs and supporting affiliated businesses. From a social standpoint, the Saudi population appreciates the availability of different recreational opportunities, including Multiplex cinemas, IMAX, and others. The popularization of the Arab cinematography is expected to strengthen cultural ties within the region.

Finally, the analysis of the collected data as applied to Saudi Arabia's economic and social environment strongly suggests the presence of high demand for the film industry. Despite the lack of information for 2018, scenario forecasting and analysis of secondary sources reveals that the cinema industry withstood the pandemic and continues to grow. By incorporating filmmaking in the existing entertainment sector, it is possible to draw from the current popularity of TV, digital media, and satellite programs. As the number of 
cinema-goers gradually increases, industry leaders are expected to satisfy the demand by opening new cinemas and establishing film studios. While the economic and cultural impacts of the motion picture industry cannot be understated, Saudi Arabia should adapt to the modern trends and demands of the Saudi population. Finally, the sheer size of the cinema industry necessitates meaningful coordination between economic and cultural spheres to ensure the creation of appropriately priced contents, services, or products.

\section{Acknowledgments}

The authors are grateful to the anonymous referees of the journal for their extremely useful suggestions to improve the quality of the article. Usual disclaimers apply.

\section{References}

Al-Jazirah. (2019). Entertainment spending is expected to rise to 36 billion riyals by 2030. https://www.aljazirah.com/2019/20190222/sy1.htm

Althaqeel, N. K. (2017). The beginning of theatre in Saudi Arabia. Performing Islam, 6(1), 23-40.

Box Office Mojo. (2020). Saudi Arabian box office weekends for 2020. https://www.boxofficemojo.com/weekend/by-year/?area=SA

Chulov, M. (2017). Saudi Arabia to lift 35-year ban on cinemas. The Guardian.

Deloitte. (2020). Economic impact of the film, television, and online video services industry in India, 2019. https://www2.deloitte.com/content/dam/Deloitte/in/Documents/about-deloitte/in-aboutdeloitte-economic-impact-of-the-film-television-and-osv-industry-noexp.pdf

Foley, S. (2019). Changing Saudi Arabia: Art, Culture, and Society in the Kingdom. Lynne Rienner Publishers, Incorporated.

Ginsberg, T., \& Lippard, C. (2020). Historical dictionary of Middle Eastern cinema. Rowman \& Littlefield Publishers.

Habibi, N. (2019). Implementing Saudi Arabia's Vision 2030: An Interim Balance Sheet. Middle East Brief, 127, 1-9.

IBISWorld. (2019). Global Movie Production \& Distribution Industry: Industry Market Research Report.

Jarjoura, N. (2014). The current state of Arab cinema: the stories of individuals... and an update on documentary films. Contemporary Arab Affairs, 7(2), 209-224.

Khan, M. B., \& Iqbal, S. (2020). 7 Vision 2030 and the National Transformation Program. Research, Innovation and Entrepreneurship in Saudi Arabia: Vision 2030, 146.

Khan, M. K., \& Khan, M. B. (Eds.). (2020). Research, Innovation and Entrepreneurship in Saudi Arabia: Vision 2030. Routledge.

Kingdom of Saudi Arabia. (2020). Saudi Vision 2030. https://vision2030.gov.sa/en

Kosow, H., \& Gaßner, R. (2008). Methods of future and scenario analysis: overview, assessment, and selection criteria (Vol. 39, p. 133). DEU.

Lakhpatwala, Z. (2020). AMC Saudi Arabia CEO upbeat about cinema prospects amid-COVID-19. Arab News, https://www.arabnews.com/node/1741401/media

Martin, J. D., Martins, R. J., \& Wood, R. (2016). Desire for cultural preservation as a predictor of support for entertainment media censorship in Saudi Arabia, Qatar, and the United Arab Emirates. International Journal of Communication, 10, 23.

Messnaoui, M. (2014). History of Arab cinema (introduction to understanding and interpretation). Contemporary Arab Affairs, 7(2), 195-208.

Montgomery, D. C., Jennings, C. L., \& Kulahci, M. (2015). Introduction to time series analysis and forecasting. John Wiley \& Sons.

Mould, O. (2016). Mediating the city: The role of planned media cities in the geographies of creative industry activity. Hub Cities in the Knowledge Economy: Seaports, Airports, Brainports, 163-80.

O'Reilly, M., \& Kiyimba, N. (2015). Advanced qualitative research: A guide to using theory. Sage. 
Oxford Business Group. (2018a). Investment in Saudi Arabia's entertainment industry to catalyse sector growth. https://oxfordbusinessgroup.com/news/investment-saudi-arabia $\% \mathrm{E} 2 \% 80 \% 99$ s-entertainmentindustry-catalyse-sector-growth

Oxford Business Group. (2018b). The Report: Saudi Arabia 2018.

Pirani, A. (2018). New Cinema Licensing Regime in Saudi Arabia. Ct. Uncourt, 5, 8.

Ruus, R., \& Sharma, R. (2019, December). Predicting Movies’ Box Office Result-A Large Scale Study Across Hollywood and Bollywood. In International Conference on Complex Networks and Their Applications (pp. 982-994). Springer, Cham.

PwC Middle East. (2020). Cinemas in Saudi Arabia: A billion dollar opportunity. https://www.pwc.com/m1/en/publications/cinemas-in-saudi-arabia-opportunity.html

Quality of Life Program. (n.d.). Quality of life program 2020. Delivery plan. https://vision2030.gov.sa/sites/default/files/attachments/QoL\%20English_0.pdf

Sarı, G. (2020). A Feminist Perspective Analysis of Gender in Cinema of Saudi Arabia: Wadja. In International Perspectives on Feminism and Sexism in the Film Industry (pp. 59-73). IGI Global.

Shafik, V. (2007). Arab cinema: History and cultural identity. American Univ in Cairo Press.

Statista Research Department. (2017). Number of performing arts in Saudi Arabia in 2016. https://www.statista.com/statistics/820128/saudi-arabia-number-of-performing-arts-events-bytype/

Tripathi, S. (2017). Role of Bollywood cinema in promoting tourism, business and intercultural communication in Arab world: A study with Oman. International Journal of Social Sciences, 3(1).

UNESCO. (2016). Diversity and the film industry. An analysis of the 2014 UIS Survey on Feature Film Statistics. http://uis.unesco.org/sites/default/files/documents/diversity-and-the-film-industry-ananalysis-of-the-2014-uis-survey-on-feature-film-statistics-2016-en_0.pdf

Vivarelli, N. (2018). IMAX Partners With Vox Cinemas on Screens in Saudi Arabia. Variety. https://variety.com/2018/biz/news/imax-saudi-arabia-vox-cinemas-screens-1202810945

Vivarelli, N. (2020). Saudi Arabia Becomes Top Middle East Theatrical Market, Bucking COVID-Era Downward Trend. Variety. https://variety.com/2020/film/global/saudi-arabia-top-middle-easttheatrical-market-1234824347

Vogel, H. L. (2020). Entertainment industry economics: A guide for financial analysis. Cambridge University Press. 